To cite this article: Campos, R., \& Araújo, M. (2017). Traditional Artistic Expressions in Science Communication in a Globalized World: Contributions From an Exploratory Project Developed in Northeast Brazil. Science Communication. First published online: July 17, 2017. DOI: $10.1177 / 1075547017721204$

To link to this article: https://doi.org/10.1177/1075547017721204

\title{
Traditional Artistic Expressions in Science Communication in a Globalized World: Contributions From an Exploratory Project Developed in Northeast Brazil
}

\section{Rita Campos 1,2 and Magnólia Araújo 3}

\begin{abstract}
Science communication projects share one main goal: to bring together academia and society. However, despite the several formats used to make this bridge, traditional artistic expressions - those that are part of the cultural identity of a group - are seldom used. These formats can be particularly relevant in a globalized world where people from different social and cultural backgrounds meet. We present a project developed in Brazil that used a traditional type of theatre and literature to engage the public in a health control program, and reflect on the potentialities of these formats to communicate science in our multicultural societies.
\end{abstract}

1CIBIO/InBIO, University of Porto, Vairão, Portugal

2CES, University of Coimbra, Coimbra, Portugal

3Federal University of Rio Grande do Norte, Natal, Brazil

\section{Corresponding Author:}

Rita Campos, Centro de Investigação em Biodiversidade e Recursos Genéticos/Rede de Investigação em Biodiversidade e Biologia Evolutiva, Associate Laboratory (CIBIO/InBIO), Campus Agrário de Vairão, 4485-661 Vairão, Portugal.

Centro de Estudos Sociais, University of Coimbra (CES-UC), Colégio de S. Jerónimo, Largo D. Dinis, Apartado 3087, 3000-995 Coimbra, Portugal

Email: rita.ml.campos@gmail.com 


\section{Keywords}

traditional artistic expressions, cultural identity, science communication, informal learning, public engagement

\section{Diversity of Science Communicating Formats}

A common goal to all science communication projects is narrowing the distance between scientists and the public, bringing both "worlds" to a dialogue with an effective channel to exchange information (Chilvers, 2013; Bucchi \& Trench, 2014). Formal academic knowledge is desirably presented in an informal language, so that the public can reflect on the topics being addressed and engage in an open and rational discussion about the topics under consid-eration. Ultimately, this proximity between expert and nonexpert knowledge will lead to a more fruitful relationship between academia and citizens and thus to a more informed society.

Keeping in mind the vast differences among publics, different formats have been tested to improve the communication process in informal learning environments (see, e.g., Horst \& Michael, 2011, for a short review of the different science communication formats). These formats include the use of comics (Spiegel, McQuillan, Halpin, Matuk, \& Diamond, 2013; Tatalovic, 2009; Varela Amaral, Forte, Ramalho-Santos, \& Girão da Cruz, 2015), music (Moreira \& Massarani, 2006), games (Campos \& Sá-Pinto, 2013; Sá-Pinto, Cardia \& Campos, 2017), theatre (Gunderson, 2006; Moreira \& Marandino, 2015; Pinto, Marçal, \& Vaz, 2013), or animated videos (McGillion, 2017; Varela Amaral et al., 2015). The main objective of these resources is to promote public engagement with science through proximity and familiarity and by triggering positive emotions (Pinto et al., 2013; Sinatra, Broughton \& Lombardi, 2014). However, when conducting a search on Google Scholar database using a combination of "traditional art" or "folk art" with "science communication" or related expressions (e.g., "traditional artistic expressions" or "communicating science") in English and in Portuguese, we retrieved very few papers. Brazil seems to be an exception, where some authors have used traditional art to communicate science-related contents or have analyzed scientific topics present in traditional artistic expressions (Almeida, Massarani, \& Moreira, 2016; Assunção \& Pinho, 2016; Moreira \& Massarani, 2006; Oliveira et al., 2014). Thus, our conclusion is that even though speaking directly to one's identity, traditional artistic expression formats, which we here consider as those that are part of the cultural identity of a given group, have seldom been use to communicate science globally. 


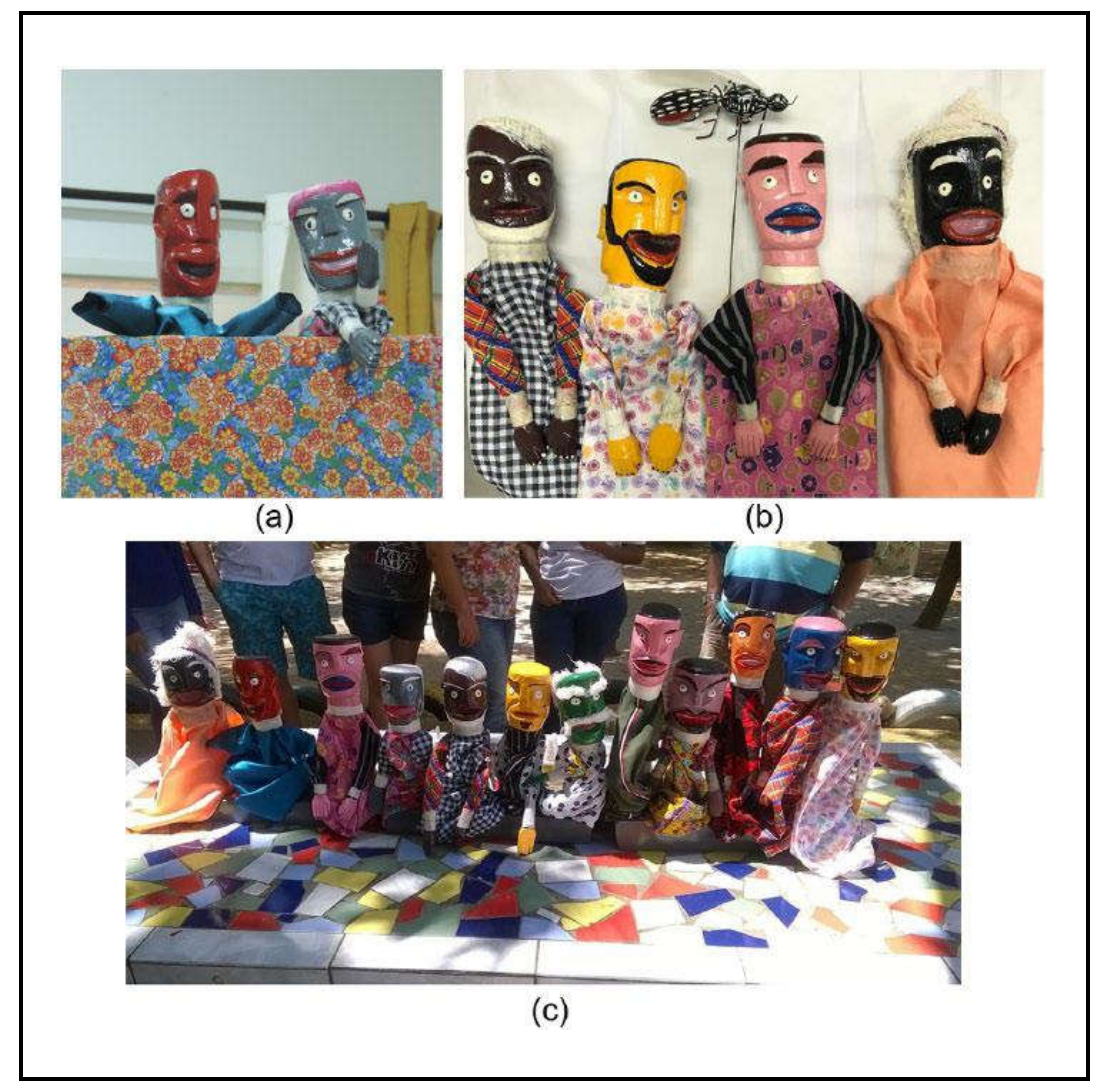

Figure 1. Wooden puppets used in mamulengo theatre: (a) during a presentation of "Zé and Zika" in a school, in the semiarid region of northeast Brazil; (b) part of the characters from the "Zé and Zika" play, including a representation of an Aedes species mosquito used during the presentation; (c) the "cast" and their creators and interpreters.

Here we discuss an exploratory science communication project developed in northeast Brazil that incorporates two formats of Brazilian traditional artis-tic expressions to engage the public in questions related to biodiversity and public health: mamulengo theatre and cordel literature. Mamulengo theatre is a Brazilian form of puppet theatre characterized by the use of wooden pup-pets dressed in colorful textiles (Figure 1), strident voices, a small and ambu-lant folding stage, and a narrative that traditionally portraits daily-life situations in a satiric way, calling the audience to interact with the puppets 


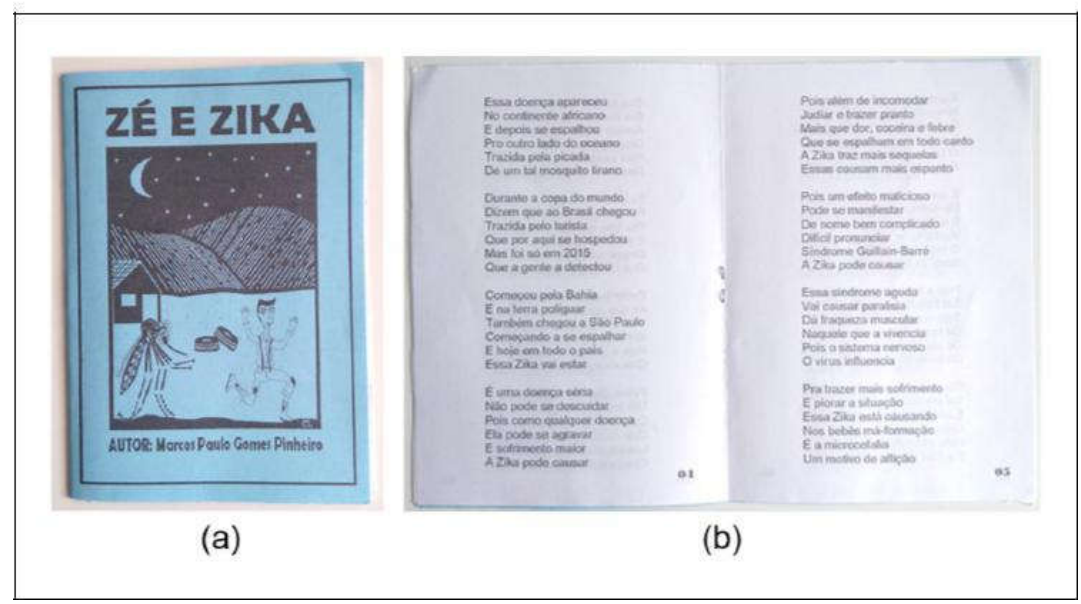

Figure 2. "Zé and Zika," an example of a cordel-type story developed for a science communication project: (a) the book cover is illustrated with a woodcut, a characteristic usually found in this type of literature; (b) in the right top corner, in the first two lines, we can read, "Because besides annoying, harassing and bringing tears (. . .)," an example of how science was used as a metaphor.

(Assunção \& Pinho, 2016; Câmara Cascudo, 2012; Oliveira et al., 2014). This puppet theatre was presumably inspired by similar forms of European theatres, such as D. Roberto in Portugal, Guignol in France, Pulcinella in Italy, or Punch in England. It also shows similarities with traditional artistic manifestations from other parts of the globe, namely, with Karagós in Turkey and Vidouchaka in India (Câmara Cascudo, 2012; Elias de Castro, 2015). Mamulengo theatre is an interactive format usually performed in a generic venue, like a village or town square, that can be used as a vehicle for higher involvement and an invitation for "idiotic behavior" (Bultitude \& Sardo, 2012; Horst \& Michael, 2011; Sardo \& Grand, 2016).

Cordel literature is a Brazilian form of traditional poetry that can be considered a direct descendant of the medieval European minstrelsy (Almeida et al., 2016). It has constant rhymes and accurate metrics and often uses local terms. The poetry depicts legends, myths, or stories from the oral tradition or daily situations, frequently using humor, and is printed as a small booklet or pamphlet sometimes illustrated with woodcuts (Figure 2). Cordel is the Portuguese word for string (and so "cordel literature" means literally "string literature") because the booklets were usually sold in the street markets where they were displayed hanging from a string. The history of cordel literature dates back from the Middle Ages in Europe, where similar formats can be 
found in Great Britain (chapbooks; see also the NYC/CUNY Chapbook Festival for modern uses of this format: http://chapbookfestival.org/), France (bibliothèque bleue), Germany (volksbuch), and Portugal and Spain (cordel).

Cordel literature is usually seen as a minor form of literature, with a long tradition of being kept apart from the "academic elites." But this format is well accepted by and attractive to the public and thus offers a good opportunity to present scientific complex topics in a simple format. Moreover, its simplicity can be used to challenge the public to contribute with their own writing, sharing different point of views on the same subject. These personal texts can give scientists new raw material to develop or adapt their science communication or research project. Recently cordel literature has been used as vehicles of information, including in science communication projects (Almeida et al. 2016). For example, this form of literature has already proven to be a good communication resource for health promotion (Pagliuca, Oliveira, Rebouças, \& Galvão, 2007).

\section{Case Study: Globalization and the Spread of Infectious diseases: The Zika Virus in Brazil}

Health communication can be seen as a niche within the field of science communication. Often, health communication and health promotion programs expect both to increase public health literacy and to bring about behavior change (e.g., Sørensen et al., 2012). Health literacy has impact in different levels, from the individual to community health, and assumes particular relevance in cases where behavior changes are essential to eradicate fast-spread-ing diseases, such as emergent infectious diseases. The economic development and migration rates experienced in recent decades worldwide have led to pro-found changes in climate and in ecosystems (Keesing et al., 2010), causing discontinuities between the established balance in ecological relationships and evolutionary processes. In terms of infectious diseases, these migratory movements and environmental disturbances facilitated rapid host changes and new geographical colonization by pathogens without giving the new host time to develop resistance (Hoberg \& Brooks, 2015; Sala, Meyerson, \& Parmesan, 2012). One of such cases is the spread of Aedes species mosquitoes globally and the outbreaks of infectious diseases in several parts of the globe.

Aedes mosquitoes are vectors for three diseases with a high prevalence rate in Brazil: dengue, zika, and chikungunya (Cardoso et al., 2015; Musso, CaoLormeau, \& Gubler, 2015). All three diseases are considered global pub-lic health threats (Cardoso et al., 2015). Northeastern Brazil is an endemic region for both dengue and chikungunya, and it was also the first region where a zika outbreak was reported (Zanluca et al., 2015). Zika virus has 
been known in Africa for several decades without causing any major health concerns; however, since 2007 it has spread from Africa and Asia, leading to large epidemic episodes. The spread was first reported in the Island of Yap (Federated States of Micronesia), and by the end of 2016 about 20 countries in the Americas had declared infectious outbreaks (Kindhauser, Allen, Frank, Santhana, \& Dye, 2016). In Brazil, this newly reported infection probably originated through migratory movements of people between South America and the rest of the world. A similar path was observed for dengue and chikun-gunya, which also spread worldwide, closely linked with globalization move-ments (Musso et al., 2015). This scenario offers ample opportunities to create spaces for a dialogue between scientists of different fields and the communi-ties affected by the diseases. An evolutionary framework allows us to under-stand and manage the (re)emergence of infectious diseases and also to develop new methodologies of approaching disease (see Stearns, Nesse, Govindaraju, \& Ellison, 2010; Vila \& Campos, 2013, for some insights on evolutionary medicine). While scientists aim to trace the evolutionary route and identify, describe, and treat instances of Aedes-borne infections, com-munities can bring to the discussion their experiences with mosquito control actions and inform about the distribution of instances of infections.

\section{Traditional Theatre and Literature Engaging Communities in Health Control Programs}

Eliminating the access of Aedes mosquitoes to water can lead to successful elimination of the vector mosquitoes and thus eradicate the diseases in the affected areas (Morrison, Zielinski-Gutierrez, Scott, \& Rosenberg, 2008). But this simple step is effective only if all member of the community take part in it. Consequently, well-organized science communication campaigns can play a fundamental role in promoting attitudinal changes in the popula-tion, leading to sustained mosquito control behaviors. With this in mind, and working with students from a Brazilian Federal University (Figure 1c), we set and evaluated a mamulengo theatre script and a cordel poetry narrative based on Aedes-borne infections (Figure 1b). The aim of the project was to stimulate a discussion with Brazilian communities in the areas affected by the Aedes-borne infections about the diseases associated with the mosquito, and their origin, symptoms, prevention, and treatment. These traditional artistic expressions formats take advantage of a very informal and humoristic approach to create a dialogue with the audience based on attitudinal changes toward mosquito control actions. In this sense, following the definition pro-posed by Gunderson (2006), science is used

as

a

metaphor,

as

the

narratives 
uses a script that "combine effective science with effective poetry to create something that is true both in the concrete and the abstract." For example, the character that narrates the cordel story refers to symptoms of zika infection as if the virus is a person: "(. . .) because besides annoying, harassing and bring-ing tears (. . .)" (Figure 2b).

The text written for this particular theatre, as well as the overall performance, followed the main aspects of the mamulengo theatre described above. The cordel book on the theme was also associated with the presentation, being distributed to the public in the beginning of the play. The poetry in this booklet recreates the theatre script. It tells a story about a character, "Zé," who falls sick with zika fever and explains to a friend the symptoms he was feeling and what the doctors told him to do to prevent further complications and to control the spread of the vector mosquitoes (Figure $2 b$ ). Both narra-tives pay special attention to the attitudes one should have in order to prevent infections and help eradicate Aedes mosquitoes.

Scientific contents play a secondary role as the audience focus on the movements of the puppets. This is in line with the major goal of the activity: to change attitudes. The puppets thus serve as role models, and the audience express their empathy toward both the puppets and their behaviors.

\section{Preliminary Evaluation of the Use of Traditional Artistic Expressions in Science Communication}

Both mamulengo and cordel were used during a visit to a rural community in the semiarid region in Northeast of Brazil to promote a dialogue related to Aedes infections. In this particular session, the audience consisted of a mixed group of teachers from different scientific areas, students attending different school grades, and some local citizens, with a total of 30 participants. The audience was recruited by the local Secretary of Education, after a previous contact with the group of scientists coordinating the project. Due to the high temperature on the day of the activity, this session took place in a classroom instead of the village central square.

To have a first insight of the usefulness of these formats in public engagement and the creation of a space for open dialogue, we conducted a prelimi-nary evaluation using a direct observation methodology, where one researcher stood aside as an outside observer during the activity. We also recorded the session for further complementary analysis of the reactions of the public. This complementary analysis was made by a second researcher who evaluated the session only through the video, using the same parameters. The guidelines for the evaluation followed a list of three main parameters: 
engagement, interactions, and integration. By engagement we mean the observation of how the audience related with the puppets, with the background context of the play, and with the science-related concepts. Under the parameter interactions we observed the connections established between the different members of the audience and between them and the play and concepts; nonverbal behaviors, such as facial expressions or gestures, were also observed. By integration we mean the observation of how the audience was making use of the concepts within the mamulengo and cordel narratives dur-ing the sessions (mostly by verbally expressing personal experiences or emo-tions to other members of the audience or to the puppets). Both researchers met after the independent evaluations to compare notes.

In general, the public expressed amusement throughout the performance. Preliminary results highlighted a high level of public engagement: the audience shared their own experiences with mosquito control efforts and interrupted the theatre with comments related to the script, to criticize some of the behaviors exhibited by the puppets, or to encourage the characters to take on actions, like seek a doctor to understand symptoms and learn major preven-tion procedures. In the end, but still in the context of the theater, the entire audience participated in a joint reading of the cordel story, along with the mamulengo puppets, which helped in reinforcing the importance of the com-munity's participation to an effective mosquito eradication program. Similar behaviors and reactions were also observed in previous presentations, in three cities and two science festivals, even though no formal evaluation was conducted in those occasions.

Based on our observations, mamulengo theatre has a potential higher level of success in particular cases where the main goal of the project is to provoke attitudinal changes. This happens due to the highly interactive nature of this theatre and the facilitation of "learning through imitation," that is, the change occurs because the consequences of a previous behavior are seen on stage. The story on the cordel book was very simple and easy to follow, as attested by the group reading, where people were responding to the more humoristic or serious aspects of the narrative accordingly. Only a longitudinal study can give us more information on their effectiveness as agents of attitudinal changes, but these preliminary results suggest that traditional artistic expres-sions might act as an excellent format to engage the public in the scientific message, which is a good indicator for better communication (Kahan, 2010).

\section{Communicating Science in Multicultural Societies}

Traditional artistic expressions have been the subject of extensive research focusing on its contribution to the sense of identity and the construction of 
intangible cultural heritages (see, e.g., Catenacci, 2005; Klimt \& Leal, 2005; Rocha, 2009), which can be particularly important in societies made up of citizens from diverse backgrounds struggling to keep an identity while adapting to new habits. When incorporated in science communication projects, traditional artistic expressions have the potential to bring together people from different cultures but with similar references. This aspect is nonnegli-gible since it can influence publics' adhesion to a particular message, and increasing scientific literacy and science-society dialogue can relate directly to levels of public identification to a communication format (Kahan, 2010).

Here we present and discuss the use of two different formats of Brazilian traditional artistic expressions: mamulengo theatre and cordel literature. Our preliminary evaluation highlighted the engagement and dialogical nature of both formats, confirming previous informal observations. In the particular context of control programs for vector-borne diseases, this high engagement might be associated with a higher disposition to behavioral change and coop-eration with health care and prevention programs. Even though our audience was not as mixed as the public found, for example, in bigger cities, it was composed of a heterogeneous group of people in terms of education, ethnic-ity, and age. We used this heterogeneity and these formats as a proxy for other multicultural societies worldwide and related traditional artistic expressions. We hypothesize that incorporating traditional artistic expressions can help design better communication projects that improve engagement and lead to a more open and consistent dialogue between academia and society.

\section{Acknowledgments}

We are thankful to all monitors of the Science Park of the Federal University of Rio Grande do Norte (Parque das Ciências-UFRN) for their work in the mamulengo and cordel session that inspired this article. Data collection was conducted during a mam-ulengo and cordel session organized by Parque das Ciências-UFRN. We also wish to thank Rita Ponce, Susanna Priest, and Linda Billings for their critical reading of a previous version of the manuscript and valuable suggestions to improve it.

\section{Declaration of Conflicting Interests}

The author(s) declared no potential conflicts of interest with respect to the research, authorship, and/or publication of this article.

\section{Funding}

The author(s) disclosed receipt of the following financial support for the research, authorship, and/or publication of this article: RC is supported by $\mathrm{POCH}$ - Programa Operacional Capital Humano and funds from the European Social Fund and the 
Portuguese Ministério da Ciência, Tecnologia e Ensino Superior, via Fundação para a Ciência e a Tecnologia (Grant SFRH/BPD/110348/2015).

\section{References}

Almeida, C., Massarani, L., \& Moreira, I. C. (2016). Representations of science and technology in Cordel literature. Bakhtiniana, 11(3), 6-28. (Article in Portuguese)

Assunção, A. M. S., \& Pinho, F. A. (2016). Mediação cultural e o teatro de mamulengo [Cultural mediation and mamulengo theatre]. In D. A. Salcedo (Ed.) Mediação cultural [Cultural mediation] (pp. 15-28). São Carlos, Brazil: Pedro \& João Editores.

Bucchi, M., \& Trench, B. (Eds.). (2014). Handbook of public communication of science and technology (2nd ed.). New York, NY: Routledge.

Bultitude, K., \& Sardo, M. (2012). Leisure and pleasure: Science events in unusual locations. International Journal of Science Education, 34, 2775-2795.

Câmara Cascudo, L. (Ed.). (2012). Dicionário do folclore brasileiro [Dictionary of Brazilian folklore] (12th ed.). São Paulo, Brazil: Global Editora.

Campos, R., \& Sá-Pinto, A. (2013). Early evolution of evolutionary thinking: Teaching evolutionary biology in elementary schools. Evolution: Education \& Outreach, 6, 25.

Cardoso, C. W., Paploski, I. A. D., Kikuti, M., Rodrigues, M. S., Silva, M .M. O., Campos, G. S., . . . Ribeiro, G. S. (2015). Outbreak of exanthematous illness asso-ciated with zika, chikungunya, and dengue viruses, Salvador, Brazil. Emergent Infection Diseases, 21, 2274-2276.

Catenacci, V. (2005). Cultura popular entre a tradição e a transformação [Popular culture between tradition and transformation]. São Paulo Perspectivas, 15, 2.

Chilvers, J. (2013). Reflexive engagement? Actors, learning, and reflexivity in public dialogue on science and technology. Science Communication, 35, 283-310.

Elias de Castro, E. (2015). O Teatro de Mamulengos de ontem e de hoje: a importân-cia do reconhecimento do Teatro de Bonecos Tradicional Brasileiro como pat-rimônio imaterial cultural do Brasil [The Mamulengo Theater of yesterday and of today: the importance of the recognition of the Brazilian Traditional Doll Theater intangible cultural heritage of Brazil]. Resgate: Revista Interdisciplinar Cultural, 23, 69-80.

Gunderson, L. (2006). Science plays come of age. The Scientist, Midland. Retrieved from http://www.the-scientist.com/news/display/24160/

Hoberg, E. P., \& Brooks, D. R. (2015). Evolution in action: Climate change, biodiver-sity dynamics and emerging infectious disease. Philosophical Transactions of the Royal Society B, 307, 20130553.

Horst, M., \& Michael, M. (2011). On the shoulders of idiots: Re-thinking science communication as "event." Science as Culture, 20(3), 1-24.

Kahan, D. (2010). Fixing the communication failure. Nature, 463, 296-297.

Keesing, F., Belden, L. K., Daszak, P., Dobson, A., Harvell, C. D., Holt, R. D., . . . Ostfeld, R. S. (2010). Impacts of biodiversity on the emergence and transmission of infectious diseases. Nature, 468, 647-652. 
Kindhauser, M. K., Allen, T., Frank, V., Santhana, R. S., \& Dye, C. (2016). Zika: The origin and spread of a mosquito-borne virus. Bulletin of the World Health Organization, 94, 675C-686C.

Klimt, A., \& Leal, J. (2005). Introduction: The politics of folk culture in the lusophone world. Etnográfica, IX, 5-17.

McGillion, C. (2017). Animation as a science communication tool in Timor-Leste. Science Communication, 39, 278-285.

Moreira, I. C., \& Massarani, L. (2006). (En)canto científico: temas de ciência em letras da música popular brasileira [Scientific (en)chant: science themes in lyrics of Brazilian popular music]. História, Ciência, Saúde-Manguinhos, 13(Suppl.), 291-307.

Moreira, L. M., \& Marandino, M. (2015). Teatro de temática científica: conceituação, conflitos, papel pedagógico e contexto brasileiro [Theater of scientific theme: conceptualization, conflicts, pedagogical role and Brazilian context]. Ciência \& Educação, 21, 511-523.

Morrison, A. C., Zielinski-Gutierrez, E., Scott, T. W., \& Rosenberg, R. (2008). Defining challenges and proposing solutions for control of the virus vector Aedes aegypti. PLoS Medicine, 5(3), e68.

Musso, D., Cao-Lormeau, V. M., \& Gubler, D. J. (2015). Zika virus: Following the path of dengue and chikungunya? The Lancet, 386, 243-244.

Oliveira, E. S., Santos, F. C., Cunha, L. A., Costa, J., Santos, M. L., \& Silva, E. V. (2014). Falando de vitamina $\mathrm{C}$ por meio do teatro de mamulengo: objectivando a popularização da ciência [Speaking of vitamin $\mathrm{C}$ through mamulengo theater: concretizing the popularization of science]. Scientia Plena, 10, 1-8.

Pagliuca, L. M. F., Oliveira, P. M. P., Rebouças, C. B. A., \& Galvão, M. T. G. (2007). Literatura de cordel: veículo de comunicação e educação em saúde [Cordel lit-erature: vehicle of health communication and education]. Texto \& Contexto: Enfermagem, 16, 662-670.

Pinto, B., Marçal, D., \& Vaz, S. G. (2013). Communicating through humour: A project of stand-up comedy about science. Public Understanding of Science, 24, 776-793.

Rocha, G. (2009). Cultura popular: do folclore ao património [Popular culture: from folklore to heritage]. Mediações, 14, 218-236.

Sala, O. E., Meyerson, L. A., \& Parmesan, C. (Eds.). (2012). Biodiversity change and human health: From ecosystem services to spread of disease. Washington, DC: Island Press.

Sardo, A. M., \& Grand, A. (2016). Science in culture. Science Communication, 38, 251-260.

Sá-Pinto, X., Cardia, P., \& Campos, R. (2017). Sexual selection: A short review on its causes and outcomes and activities to teach evolution and the nature of science. The American Biology Teacher, 79, 131-139.

Sinatra, G. M., Broughton, S. H., \& Lombardi, D. (2014). Emotions in science educa-tion. In R. Pekrun \& L. Linnenbrink-Garcia (Eds.), International handbook of emotions in education (pp. 415-436). New York, NY: Routledge.

Sørensen, K., Broucke, S. V. den, Fullam, J., Doyle, G., Pelikan, J., Slonska, Z., \& Brand, H. (2012). Health literacy and public health: A systematic review and integration of definitions and models. BMC Public Health, 12, 80. 
Spiegel, A. N., McQuillan, J., Halpin, P., Matuk, C., \& Diamond, J. (2013). Engaging teenagers with science through comics. Research in Science Education, 43, 2309-2326.

Stearns, S. C., Nesse, R. M., Govindaraju, D. R., \& Ellison, P. T. (2010). Evolutionary perspectives on health and medicine. Proceedings of the National Academy of Sciences of the United States of America, 107, 1691-1695.

Tatalovic, M. (2009). Science comics as tools for science education and communication: A brief, exploratory study. Journal of Science Communication, 8(4). Retrieved from https://jcom.sissa.it/sites/default/files/documents/ Jcom0804\%282009\%29A02.pdf

Varela Amaral, S., Forte, T., Ramalho-Santos, J., \& Girão da Cruz, M. T. (2015) I want more and better cells! An outreach project about stem cells and its impact on the general population. PLoS ONE, 10(7), e0133753.

Vila, J., \& Campos, R. (2013). Medicina evolutiva [Evolutionary medicine]. In R. Campos (Ed.), Um livro sobre evolução [A book about evolution] (pp. 111-114). Porto, Portugal: Centro de Investigação em Biodiversidade e Recursos Genéticos.

Zanluca, C., Melo, V. C. A., Mosimann, A. L. P., Santos, G. I. V., Santos, C. N. D., \& Kleber, L (2015). First report of autochthonous transmission of Zika virus in Brazil. Memórias do Instituto Oswaldo Cruz, 110, 569-572.

\section{Author Biographies}

Rita Campos graduated in biology from University of Porto and is currently a postdoc-toral fellow in two I\&D units from the University of Porto and University of Coimbra. She is an evolutionary biologist recently converted to science communication and non-formal education. Her main interests include the organization and evaluation of projects that promote a dialogue between academia and society and public engagement with science, specifically with topics related to evolution and biodiversity.

Magnólia Araújo graduated in biology from the Federal University of Rio Grande do Norte and is a permanent professor at this institution. She has experience in environ-mental microbiology and studies the water quality of reservoirs in the Brazilian semi-arid region. She has investigated about learning difficulties and alternative concep-tions of teachers and students of basic education in biology contents and uses science communication and education for sustainability as elements for mitigation of the stud-ied problems. 